\title{
INFLUENCE OF SAMARIUM ON THE MICROSTRUCTURE AND MECHANICAL PROPERTIES OF Mg-Y-Zn-Zr ALLOYS
}

\author{
VPLIV SAMARIJA NA MIKROSTRUKTURO IN MEHANSKE \\ LASTNOSTI Mg-Y-Zn-Zr ZLITIN
}

\author{
Wenli Wang, Yulong Qiu, Jingda Jia, Xin Yan, Wei Zhang \\ Xi' an University of Architecture and Technology, School of Metallurgical Engineering, No. 13, Yanta Road, Xi'an, China \\ wangwl@nwpu.edu.cn
}

Prejem rokopisa - received: 2017-10-13; sprejem za objavo - accepted for publication: 2018-01-09

\author{
doi: $10.17222 / \mathrm{mit} .2017 .175$
}

\begin{abstract}
The effects of the Sm element on the microstructure of $\mathrm{Mg}-3 \mathrm{Y}-2 \mathrm{Zn}-0.6 \mathrm{Zr}(w / \%)$ casting alloys were investigated, and the mechanical properties of the alloys were also tested at room temperature and different high temperatures of $(423,473,523$ and 573) K. Due to a heterogeneous nucleation, more refined grains were obtained with an increment of the Sm element. The precipitated phase at the grain boundaries changed from a discontinuous distribution to a continuous mesh. The main phase compositions were $\alpha-\mathrm{Mg}, \mathrm{W}$ phase- $\mathrm{Mg}_{3}(\mathrm{Y}, \mathrm{Sm})_{2} \mathrm{Zn}_{3}$ and $\mathrm{X}$ phase- $\mathrm{Mg}_{12}(\mathrm{Y}, \mathrm{Sm}) \mathrm{Zn}$. The Y atoms were partly replaced by $\mathrm{Sm}$ in the secondary phase. The proportion of the substitutional solid solution increased and Sm-containing phases were not found in the alloy. With the increasing Sm amount, the tensile strength and yield strength increased slightly while the elongation decreased significantly at room temperature. However, the tensile strength at high temperatures decreased at first and then increased. As the temperature increased, the fracture of the MS alloys changed from the main intergranular fracture to a transgranular fracture.
\end{abstract}

Keywords: Mg-Y-Zn-Zr alloy, samarium (Sm), microstructure, mechanical properties

Avtorji v prispevku opisujejo raziskave vpliva dodatka kemijskega elementa samarija (Sm) na mikrostrukturo zlitine Mg-3Y-2Zn-0.6Zr $(w / \%)$ v litem stanju. Prav tako so določili mehanske lastnosti zlitine pri sobni in različnih povišanih temperaturah $(423,473,523$ and 573$)$ K. Z dodatkom Sm so zaradi heterogene nukleacije dobili bolj drobno zrnato mikrostrukturo zlitine. Morfologija diskontinuirno porazdeljenih faz, izločenih na mejah med kristalnimi, se je spremenila $v$ kontinuirno porazdeljeno mrežo. V fazni sestavi zlitine so bile kot glavne faze prisotne $\alpha-\mathrm{Mg}, \mathrm{W}$ faza $-\mathrm{Mg}_{3}\left(\mathrm{Y}, \mathrm{Sm}_{2} \mathrm{Zn}_{3}\right.$ in $\mathrm{X}$ faza - $\mathrm{Mg}_{12}(\mathrm{Y}, \mathrm{Sm}) \mathrm{Zn}$. Itrijevi (Y) atomi so bili delno nadomeščeni s Sm v drugi fazi. S povečevanjem deleža substitucijske trdne raztopine se je zmanjševal delež faz v katerih ni bilo najti Sm. Z naraščajočo vsebnostjo Sm sta se rahlo povečali meja plastičnosti in natezna trdnost zlitine, medtem ko se je raztezek znatno znižal pri sobni temperaturi. Natezna trdnost zlitine se je s poviševanjem temperature najprej znižala potem pa ponovno narasla. Z naraščajočo temperaturo se je morfologija preloma zlitine spremenila iz pretežno intergranularnega (po kristalnih mejah) v transgranularni prelom (preko kristalnih zrn).

Ključne besede: Mg-Y-Zn-Zr zlitina, samarij (Sm), mikrostruktura, mehanske lastnosti

\section{INTRODUCTION}

Magnesium and its alloys are among the lowest-density-structure materials used in industry. ${ }^{1}$ Magnesium alloys are used widely in the automotive, electronics, aerospace, national defense and other fields due to the high specific strength, specific stiffness, machining properties, vibration-reduction and noise-reduction performance of these alloys. ${ }^{2-5}$

Rare-earth elements can remove oxygen and hydrogen from magnesium alloys to improve the casting performance, especially the high-temperature strength and creep resistance. ${ }^{6,7}$ The addition of rare-earth elements belonging to different subgroups (cerium subgroup and yttrium subgroup) can further enhance the strength of magnesium alloys. ${ }^{8}$ Among all of these rareearth elements, $\mathrm{Y}$ is the most effective for improving the mechanical properties of magnesium alloys at high temperatures. Thus, a series of high-temperature-resistant magnesium were developed, such as WE54 and WE43. ${ }^{9,10}$ The formation of high-temperature stable pha- ses and layers of long-period stacking-ordered (LPSO) structures can greatly enhance the creep resistance when both $\mathrm{Y}$ and $\mathrm{Zn}$ are added to magnesium alloys. ${ }^{11}$

The maximum solid solubility of elemental $\mathrm{Sm}$ in a magnesium solid solution occurs at $5.8 \%$ mass fraction (0.99\% atom fraction). Adding elemental Sm to cast magnesium alloys has beneficial effects on the solution strengthening, fine-grain strengthening and aging strengthening, but heavier rare-earth elements ( $\mathrm{Gd}$ to $\mathrm{Yb}$ ) require an addition of more than $10 \%$ mass fraction to obtain similar effects. ${ }^{12}$ Previous studies ${ }^{13-17}$ show that the strength of a magnesium alloy was significantly improved at both room and higher temperatures after additions of moderate amounts of elemental Sm. Its strengthening mechanism is related to the solid-solution strengthening, grain-refining strengthening and precipitation strengthening. As a result, it is necessary to replace the heavy rare-earth element $\mathrm{Y}$ with the more effective Sm as it is a light rare-earth element allowing reduced costs and an improved performance. 
In this study, Mg-3Y-2Zn-0.6Zr-xSm ( $x=1,2,3,3.5)$ $(w / \%)$ series alloys were investigated using mixed-protective-gas studies. Compositions with different percentages of $\mathrm{Sm}$ were added to promote the alloy strengthening as well as the solid solution and precipitation strengthening. The Sm content was not higher than $3.5 \%$ to avoid a reduction in the alloy plasticity. The effects of the Sm content on the microstructure and mechanical properties of the alloys at room temperature and high temperatures were studied.

\section{EXPERIMENTAL PART}

The prepared raw materials were a pure $\mathrm{Mg}$ ingot (99.98\% mass fraction), a pure $\mathrm{Zn}$ ingot $(99.98 \%$ mass fraction), the $\mathrm{Mg}-\mathrm{Y}$ master alloy (30.10\% mass fraction), the $\mathrm{Mg}-\mathrm{Sm}$ master alloy (30.07\% mass fraction) and the Mg-Zr master alloy (29.09\% mass fraction). Table 1 gives the nominal chemical compositions of the tested alloys.

Table 1: Nominal chemical compositions of the tested alloys, in mass fractions $(w / \%)$

\begin{tabular}{|c|c|c|c|c|c|}
\hline Alloys & Y & Zn & Zr & Sm & Mg \\
\hline MS1 & 3 & 2 & 0.6 & 1 & Bal. \\
\hline MS2 & 3 & 2 & 0.6 & 2 & Bal. \\
\hline MS3 & 3 & 2 & 0.6 & 3 & Bal. \\
\hline MS4 & 3 & 2 & 0.6 & 3.5 & Bal. \\
\hline
\end{tabular}

The alloys were melted in a pit furnace under a mixed-protective-gas atmosphere of $1 \% \mathrm{SF}_{6}+99 \% \mathrm{CO}_{2}$ (volume fractions). Raw materials were heated to $493 \mathrm{~K}$ and kept at this temperature for $30 \mathrm{~min}$. The protective gas was then added into the furnace and pure $\mathrm{Mg}$ was

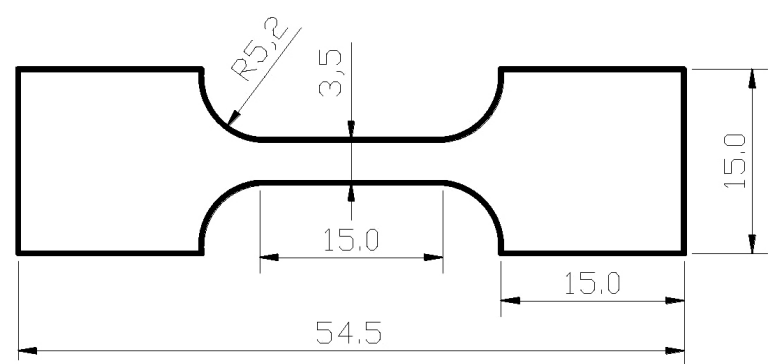

(a)

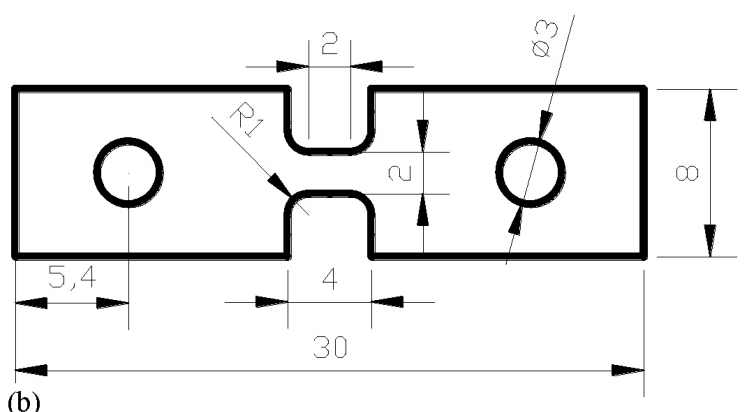

(b)

Figure 1: Flat dog-bone-shaped samples used for tensile tests: a) at room temperature, b) at a high temperature added at $1023 \mathrm{~K}$. The pure $\mathrm{Zn}$ was added and stirred in acutely after the pure $\mathrm{Mg}$ melted, and then the $\mathrm{Mg}-\mathrm{Sm}$ and $\mathrm{Mg}-\mathrm{Y}$ master alloys were added in sequence. The temperature was increased to $1053 \mathrm{~K}$ and the $\mathrm{Mg}-\mathrm{Zr}$ master alloy was added after slagging off. Hexachloride was added for refinement at $1023 \mathrm{~K}$ before the argon gas was added to the reaction chamber. The slagging off was conducted for 6-8 min after the stirring, and the reaction mixture then rested for $25-30 \mathrm{~min}$. When the temperature was reduced to $1003 \mathrm{~K}$, samples were cast immediately using the mixed protective gas after the slagging off. A casting mold was made using mild steel and heated at $493 \mathrm{~K}$ for $30 \mathrm{~min}$. Finally, the ingot was removed and water cooled for 3-5 min.

Energy dispersive spectroscopy (EDS) and fractographic feature analysis of the alloys were conducted using scanning electron microscopy (SEM, JSM-6460). Optical images of the as-cast MS alloys were collected using optical microscopy (OM, OLMPAS-GX51). The etching agent used here comprised 3-5 g picric acid, $10 \mathrm{~mL}$ water, $5 \mathrm{~mL}$ acetic acid and $90 \mathrm{~mL}$ alcohol, with etching times of 10-15 s. Tensile tests were carried out using an INSTRON 8801 testing machine, where the tensile speed was $0.5 \mathrm{~mm} / \mathrm{min}$ and the test temperatures were $(423,473,523$ and 573) K. The samples were held at the selected temperature for $10 \mathrm{~min}$. Dog-bone-shaped flat samples (Figure 1) were cut into 2-mm-thick samples. Three samples were tested and the average was recorded for each group. The phases of the samples were analyzed with D/max-RA type X-ray diffraction (XRD).

\section{RESULTS AND DISCUSSION}

\subsection{Microstructure}

The optical microstructures of the alloys are shown in Figure 2. The addition of Sm had a significant effect on the grain size; the average grain size decreased with the increasing Sm content (1-3.5\% of mass fractions) and

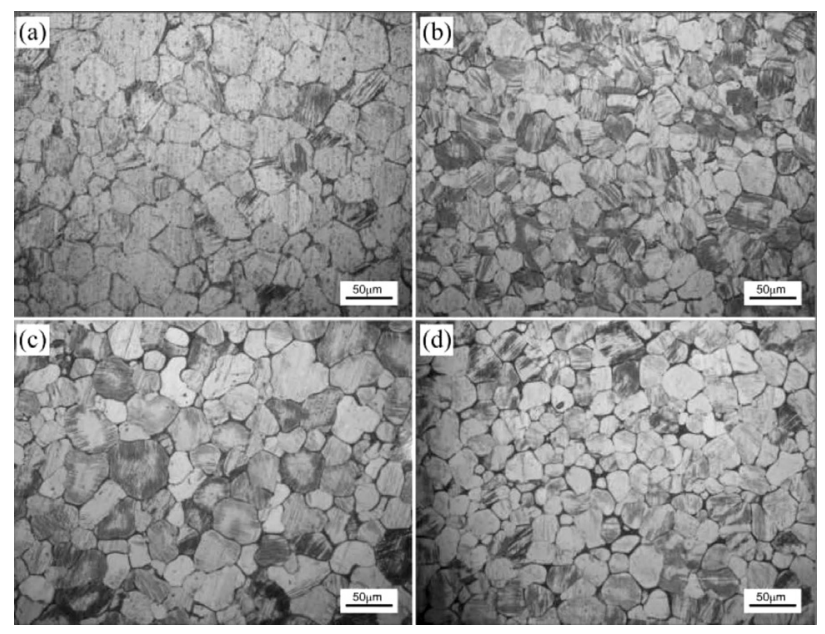

Figure 2: Optical images of the as-cast test MS alloys: a) MS1, b) MS2, c) MS3, d) MS4 

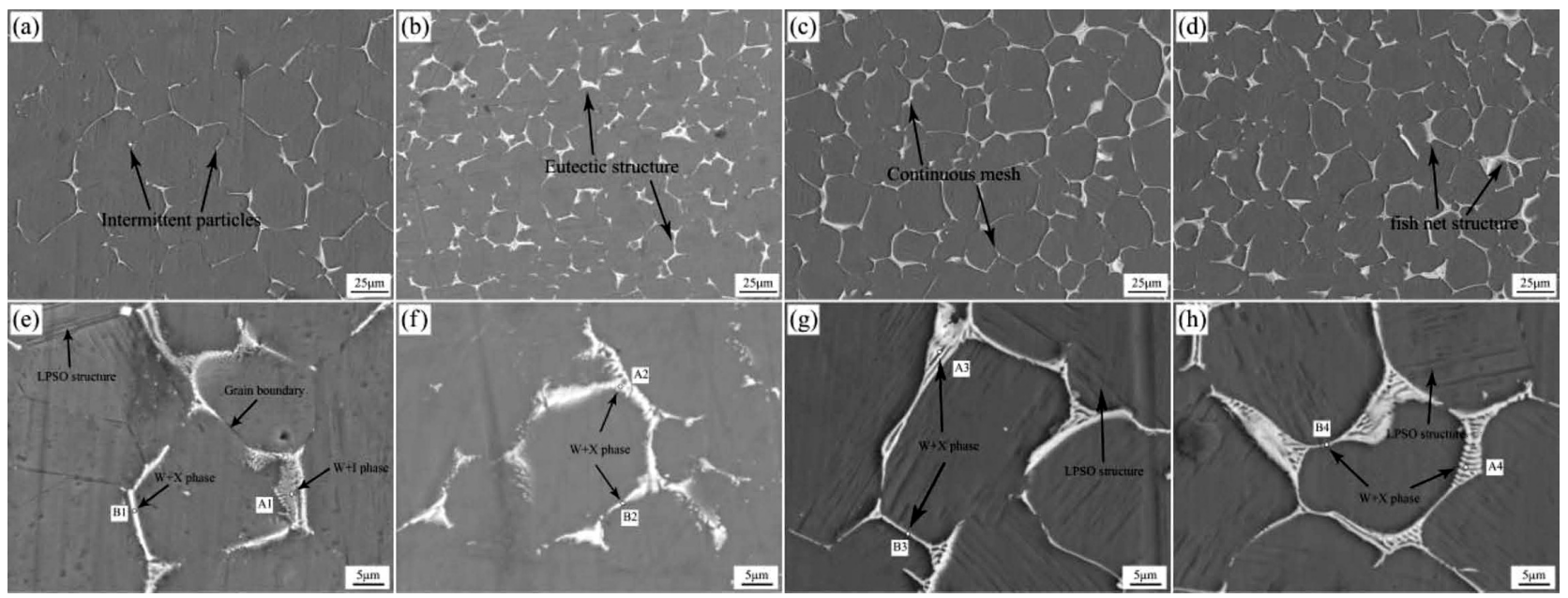

Figure 3: SEM micrographs of as-cast alloys: a), b), c), d) MS1, MS2, MS3, MS4; e), f), g), h) magnified images of a), b), c), and d)

Table 2: Chemical compositions of the tested alloys, in amount fractions $(a / \%)$

\begin{tabular}{|c|c|c|c|c|c|c|c|c|}
\hline Element & $\mathrm{A} 1$ & $\mathrm{~B} 1$ & $\mathrm{~A} 2$ & $\mathrm{~B} 2$ & $\mathrm{~A} 3$ & $\mathrm{~B} 3$ & $\mathrm{~A} 4$ & $\mathrm{~B} 4$ \\
\hline $\mathrm{Mg}$ & 81.95 & 79.99 & 78.35 & 69.11 & 75.88 & 84.00 & 77.48 & 79.51 \\
\hline $\mathrm{Y}$ & 5.22 & 7.09 & 5.79 & 8.47 & 5.60 & 4.01 & 4.55 & 5.12 \\
\hline $\mathrm{Sm}$ & 1.46 & 2.32 & 4.22 & 6.55 & 7.15 & 4.17 & 6.90 & 5.23 \\
\hline $\mathrm{Zn}$ & 11.37 & 10.60 & 11.63 & 15.87 & 11.36 & 7.82 & 11.07 & 10.13 \\
\hline$(\mathrm{Y}, \mathrm{Sm}) / \mathrm{Zn}$ & 0.58 & 0.89 & 0.86 & 0.95 & 1.12 & 1.05 & 1.03 & 1.02 \\
\hline
\end{tabular}

was in a range of $37-18 \mu \mathrm{m}$. This is because the lattice constants and atomic radii of $\mathrm{Mg}$ and $\mathrm{Sm}$ are very close to each other; according to the principle of the size structure of grain cores, ${ }^{18} \mathrm{Sm}$ atoms can become crystalline nuclei of $\alpha-\mathrm{Mg}$, playing a more pronounced role in the grain refinement.

Figure 3 shows SEM images of the as-cast alloys. A small amount of intermittent particles are distributed along the grain boundaries at $1 \%$ Sm content (Figure 3a). The eutectic structure is distributed along the trigeminal grain boundary, and the grains can be obviously refined with an addition of $2 \% \mathrm{Sm}$. The number and area of grain boundaries increase and at $3 \% \mathrm{Sm}$, the amount of the eutectic structure is further increased. Most of the eutectic phases are connected into a network, especially at the junction of triple junctions, forming a small-area fish-net structure with a non-uniform distribution. When the Sm content further increases to $3.5 \%$, the reticular eutectic volume further increases and becomes interconnected into a larger area of the fish-net structure.

As the Sm content increases, the $\mathrm{W}$ phase of the grain boundary is distributed as a continuous network. It is noted that the lamellar structure appears in the interior of the $\alpha-\mathrm{Mg}$ grains. According to Y. Kawamura and E. Abe et al., ${ }^{19,20}$ this lamellar microstructure is an LPSO structure. The results of the EDS analysis for selected alloy positions (Figures 3e-h) are shown in Table 2. The XRD analysis was carried out on four kinds of alloys with different Sm contents, and the XRD patterns are shown in Figure 4. Considering Figure 4 and Table
2, the four alloys are mainly composed of $\mathrm{Mg}, \mathrm{Y}, \mathrm{Zn}$ and Sm. Based on the XRD and EDS analyses, no new Sm phase is present in the alloys after increasing the amount of added $\mathrm{Sm}$, and $\mathrm{Sm}$ dissolves in the $\mathrm{I}\left(\mathrm{Mg}_{3} \mathrm{YZn}_{6}\right), \mathrm{W}$ $\left(\mathrm{Mg}_{3} \mathrm{Y}_{2} \mathrm{Zn}_{3}\right)$ and $\mathrm{X}\left(\mathrm{Mg}_{12} \mathrm{YZn}\right)$ phases. The replacement solid solution is formed in the secondary phase, and its proportion increases with the increasing Sm content. Due to the non-equilibrium solidification of the MS1 alloy, only a small amount of the I phase $\mathrm{Mg}_{3}(\mathrm{Y}, \mathrm{Sm}) \mathrm{Zn}_{6}$ is present at the grain boundary of the fishbone eutectic phase. The microstructure is composed of $\alpha-\mathrm{Mg}+\mathrm{W}$ phase $\mathrm{Mg}_{3}(\mathrm{Y}, \mathrm{Sm})_{2} \mathrm{Zn}_{3}+\mathrm{I}$ phase $\mathrm{Mg}_{3}(\mathrm{Y}, \mathrm{Sm}) \mathrm{Zn}_{6}$. As the

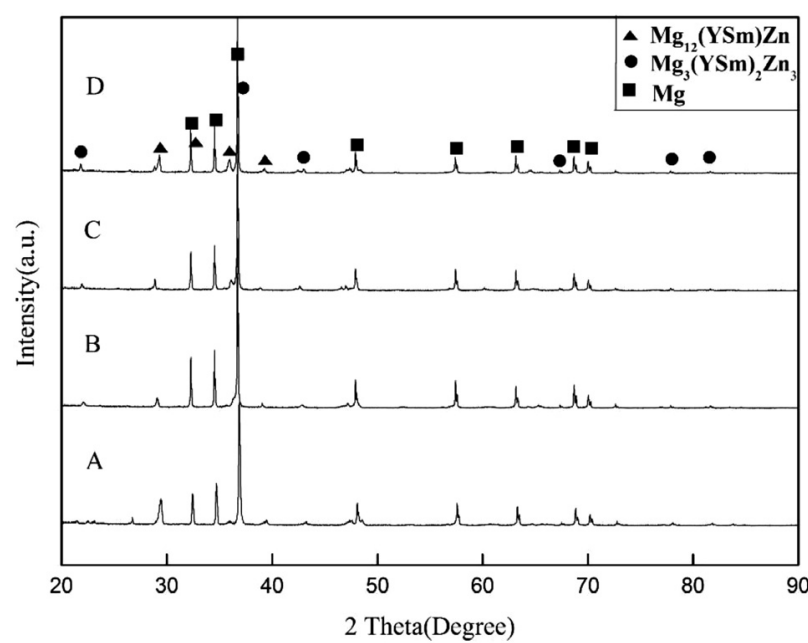

Figure 4: XRD patterns of MS series alloys with different Sm contents: a) MS1, b) MS2, c) MS3, d) MS4 
Sm content increases, the I phase eventually disappears. The ratio of the sum of the $\mathrm{Sm}$ and $\mathrm{Y}$ atomic fraction and the $\mathrm{Zn}$ atomic fraction is close to $1: 1$, and based on this and the XRD analysis, the microstructure is composed of $\alpha-\mathrm{Mg}+\mathrm{W}$ phase $\mathrm{Mg}_{3}(\mathrm{Y}, \mathrm{Sm})_{2} \mathrm{Zn}_{3}+\mathrm{X}$ phase $\mathrm{Mg}_{12}(\mathrm{Y}$, $\mathrm{Sm}) \mathrm{Zn}$.

\subsection{Mechanical properties}

\subsubsection{Mechanical properties at room temperature}

Figure 5 shows the tensile test results at room temperature. The strength and yield strength of the alloys increase with the increasing Sm content, but the elongation decreases. This is due to the grain refinement and increasing intergranular eutectic phase, which contribute to the improved strength, especially improving the yield strength of the alloy. The increase of the eutectic phase can effectively prevent a dislocation slip and increase the strength. The eutectic phase may be the source of the cracking in a deformation process, and the plasticity can be significantly reduced, decreasing the elongation. The MS4 alloy contains the highest amount of Sm in this study, and generates a large amount of net-like-structure eutectic phase; the tensile strength and yield strength are significantly higher than those of the other alloys, but the elongation is seriously deteriorated.

\subsubsection{Mechanical properties at high temperatures}

The tensile-strength results for the four alloys at different temperatures are shown in Figure 6. It is evident that in the MS1 and MS4 alloys, the high-temperature tensile properties are better than those of the MS2 and MS3 alloys. The tensile strength of the MS4 alloy at $573 \mathrm{~K}$ can reach $188.4 \mathrm{MPa}$, and the tensile strength of the ML19 (Mg-Y-Nd-Zn-Zr) alloy at $573 \mathrm{~K}$ is only 150 $\mathrm{MPa}{ }^{1}$

At high temperatures, the diffusion rate of the precipitation phase along the grain boundary is accelerated and the grain boundaries have viscosity characteristics, having a combined effect on the resistance to deformation and the relative sliding of the grains along the grain

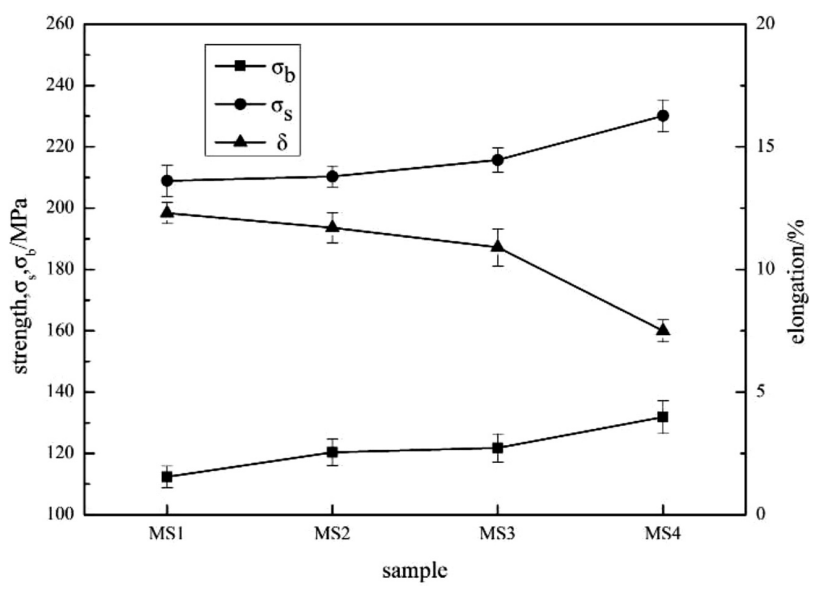

Figure 5: Tension test data for MS alloys at room temperature

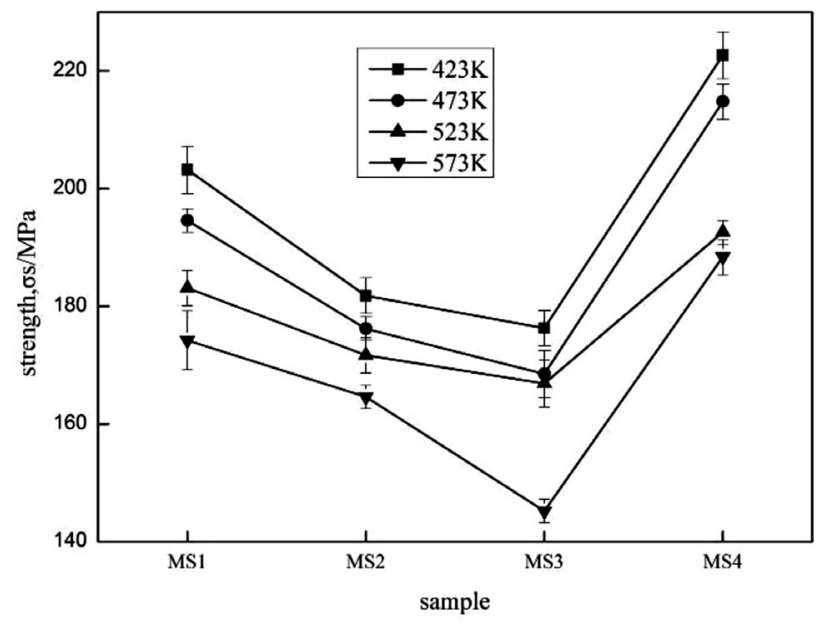

Figure 6: Tension test data for MS alloys at high temperatures

boundaries. As the temperature is increased, the magnesium alloy evolves from a single-slip system to a multi-slip system. Under the action of the strain, the dislocation climb and grain-boundary sliding also help to relieve the stress concentration. The growth and diffusion rate of microcracks and micropores decrease. Therefore, the high-temperature ductility increases and brittle fracturing is delayed. The eutectic structure at the grain boundaries of the MS2 and MS3 alloys is less pronounced and more discontinuous. The increase in the grain boundaries caused by the grain refinement leads to a slip of the grain boundaries at high temperatures. Thus, the slip at the grain boundaries at high temperatures is promoted, which is beneficial for crack propagation. At high temperatures, the MS1 alloy has a high tensile strength due to its large grains, fewer grain boundaries and a reduced amount of weak boundaries. The MS4 alloy has a high thermal stability due to the grain-boundary distribution of the continuous mesh and thin strips and effective pinning on the grain boundaries. Therefore, the tensile properties of the MS4 alloy at high temperature are the most ideal.

\subsection{Fracture behavior}

The fracture morphology of the MS series alloys at room temperature is shown in Figure 7. Quasi cleavage fractures and intergranular fractures are mixed, indicating a brittle fracture morphology. Rock candy-like grains are present due to the intergranular fracture and discontinuous brittle eutectic phase at the grain boundaries. When the plastic deformation reaches a certain stage, micropores are formed at the boundaries of the brittle secondary phase. Further growth and connections lead to intergranular fracturing, and some tearing ridges and a few dimples can be observed on the fracture surface. Secondary cracks exist in the MS4 alloy due to the secondary phase continuously distributed along the grain boundaries. The sources of fracturing caused by the tearing function of the coarse secondary phase and the 


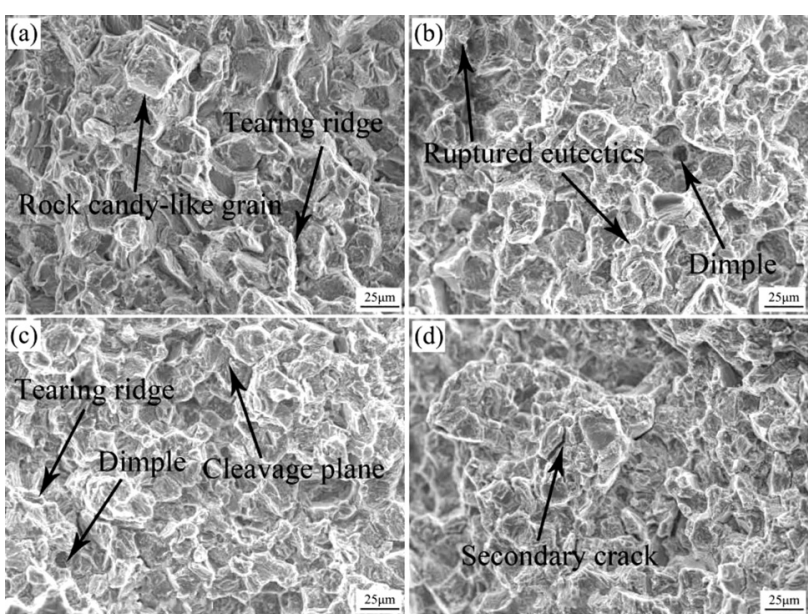

Figure 7: SEM fractographs of as-cast MS alloys at room temperature: a) MS1, b) MS2, c) MS3, d) MS4

matrix prevent further plastic deformation. The fracture occurs mainly in the secondary phase and at the junction of the secondary phase and the matrix.

Figure 8 shows the tensile-fracture morphology of the MS4 alloy at temperatures of $(423,473,523$ and $573) \mathrm{K}$. The tensile-fracture morphology at high temperatures is similar to that at room temperature. The fracture morphology at $423 \mathrm{~K}$ is mainly composed of small cleavage planes and reduced secondary phase, and intergranular fracturing is the leading fracture mode. At $573 \mathrm{~K}$, the cleavage planes increase and the secondary phase precipitates more, showing transgranular fracturing. As the temperature increases, the fracture morphology changes from intergranular fracturing to transgranular fracturing; the grains grow slightly and the secondary-phase particles increase.

The fracture occurs without much work hardening due to the dislocations - only caused by the slips at the base level $<a>$ at room temperature so the plastic-deformation ability is poor. At low temperatures, the alloy can undergo fewer slips, producing stress concentrations in the brittle secondary phase at the grain boundaries. As such, it expands easily with the cracks along the grain boundaries. As the temperature increases, the prismatic slip and pyramidal slip $<c+a>$ activate, the plastic-deformation ability improves and can be effectively processed through hardening, thus showing a higher ultimate strength. At high temperatures, the grain boundaries are weaker than the crystals, but the MS alloy with a good thermal stability due to the stable phase particles (W phase) can effectively restrain the grain boundaries and prevent the grain growth. ${ }^{21}$ The mechanical properties show that the strength is not greatly reduced, but the plasticity is significantly improved.

\section{CONCLUSIONS}

The grains of MS alloys are refined by increasing the $\mathrm{Sm}$ content. The eutectic phases precipitate at the grain

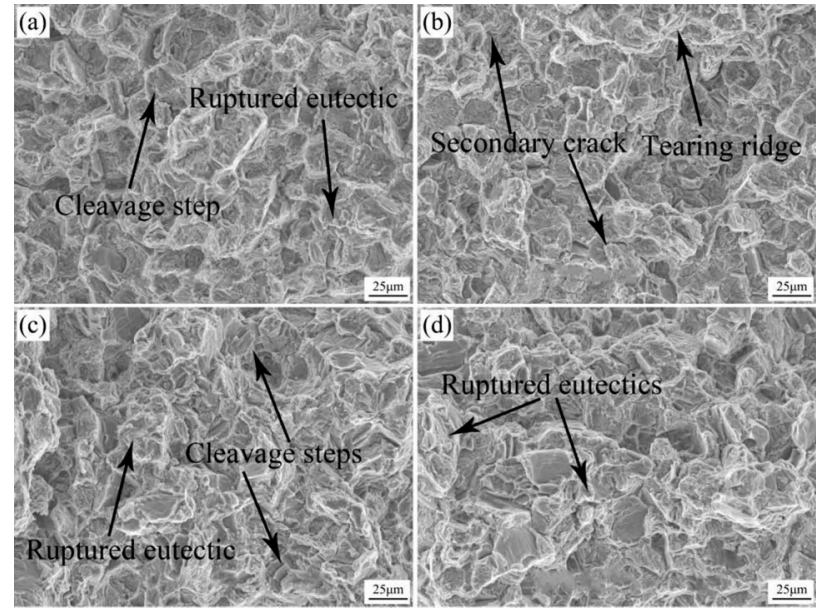

Figure 8: SEM fractographs of MS4 alloy at various temperatures: a) $423 \mathrm{~K}$, b) $473 \mathrm{~K}$, c) $523 \mathrm{~K}$, d) $573 \mathrm{~K}$

boundaries and connect to continuous meshes and thin strips.

The addition of elemental Sm affects the secondary phase by replacing the solid solution instead of forming a new Sm-containing phase. The proportion of the Sm replacing $\mathrm{Y}$ increases with the increasing amounts of Sm. The as-cast alloy is composed of $\alpha-\mathrm{Mg}+$ $\mathrm{Mg}_{3}(\mathrm{Y}, \mathrm{Sm})_{2} \mathrm{Zn}_{3}+\mathrm{Mg}_{12}(\mathrm{Y}, \mathrm{Sm}) \mathrm{Zn}$.

At room temperature, the tensile strength, yield strength and elongation of MS4 are 230.1 MPa, 131.9 $\mathrm{MPa}$ and $7.5 \%$, respectively, and the tensile strength is 188.4 $\mathrm{MPa}$ at $573 \mathrm{~K}$. These are the best comprehensive properties obtained in this study due to the grain refinement and a large number of eutectic structures along the grain boundaries.

As the stretching temperature increases, the MS alloy tensile-fracture morphology changes from the main intergranular fracturing into transgranular fracturing.

\section{Acknowledgment}

This work was supported by the Shaanxi Science and Technology Nova Project (no. 2012KJXX-33), Xi' an Science and Technology Project (no. CXYJZKD003) and Yulin Science and Technology Project.

\section{REFERENCES}

${ }^{1}$ Z. H. Chen, Heat-resistant magnesium alloy, $1^{\text {st }}$ ed., Chemical Industry Press, Beijing, 2007, 9-23

${ }^{2}$ A. A. Luo, R. K. Mishra, B. R. Powell, A. K. Sachdev, Magnesium alloy development for automotive applications, Materials Science Forum, 706-709 (2012), 69-82

${ }^{3}$ X. H. Chen, Y. X. Geng, F. S. Pan, Research progress in magnesium alloys as functional materials, Rare Metal Materials \& Engineering, 45 (2016) 9, 2269-2274, doi:10.1016/S1875-5372(17)30015-2

${ }^{4}$ A. A. Luo, Fundamentals of Magnesium Alloy Metallurgy, $1^{\text {st }}$ ed., Woodhead Publishing Limited, Cambridge, 2013, 266-316, doi:10.1533/9780857097293.266 
${ }^{5}$ M. Gupta, W. L. E Wong, Magnesium-based nanocomposites: Lightweight materials of the future, Materials Characterization, 105 (2015), 30-46, doi:10.1016/j.matchar.2015.04.015

${ }^{6}$ J. F. Nie, Precipitation and hardening in magnesium alloys, Metallurgical and Materials Transactions A, 43 (2012) 11, 3891-3939, doi:10.1007/s11661-012-1217-2

${ }^{7}$ H. C. Pan, Y. P. Ren, H. Fu, H. Zhao, L. Q. Wang, X. Y. Meng, G. W. Qin, Recent developments in rare-earth free wrought magnesium alloys having high strength: a review, Journal of Alloys and Compounds, 663 (2016), 321-331, doi:10.1016/j.jallcom.2015.12.057

${ }^{8}$ L. L. Rokhlin, T. V. Dobatkina, N. I. Nikitina, Constitution and properties of the ternary magnesium alloys containing two rare-earth metals of different subgroups, Materials Science Forum, 419 (2003), 291-296, doi:10.4028/www.scientific.net/MSF.419-422.291

${ }^{9}$ H. S. Jiang, M. Y. Zheng, X. G. Qiao, K. Wu, Q. Y. Peng, S. H Yang, Y. H. Yuan, J. H. Luo, Microstructure and mechanical properties of WE43 magnesium alloy fabricated by direct-chill casting, Materials Science and Engineering A, 684 (2017), 158-164, doi:10.1016/j.msea.2016.11.009

${ }^{10}$ J. L. Li, R. S. Chen, Y. Q. Ma, W. Ke, Effect of Zr modification on solidification behavior and mechanical properties of $\mathrm{Mg}-\mathrm{Y}-\mathrm{RE}$ (WE54) alloy, Journal of Magnesium and Alloys, 1 (2013) 4, 346-351, doi:10.1016/j.jma.2013.12.001

${ }^{11}$ B. Chen, C. Lu, D. L. Lin, X. Q. Zeng, Effect of zirconium addition on microstructure and mechanical properties of $\mathrm{Mg}(97) \mathrm{Y} 2 \mathrm{Zn} 1$ alloy, Transactions of Nonferrous Metals Society of China, 22 (2012) 4, 773-778, doi:10.1016/S1003-6326(11)61244-2

${ }^{12}$ B. L. Mordike, Creep-resistant magnesium alloys, Materials Science and Engineering A, 324 (2002) 1, 103-112, doi:10.1016/S09215093(01)01290-4

${ }^{13}$ X. Y. Yang, Y. X. Sun, H. K. Mao, H. Xu, Effect of microstructure and corrosion resistance of magnesium alloys with $\mathrm{Sm}$, Hot Working Technology, 44 (2015) 6, 77-80
${ }^{14}$ Q. A. Li, K. J. Li, X. T. Jing, J. Chen, X. Y. Zhang, Effects of Sm on microstructure and mechanical properties of AZ61 alloys, Transactions of Materials and Heat Treatment, 31 (2010) 1, 100-104

${ }^{15}$ Y. Zhang, X. F. Huang, Y. Li, Z. D. Ma, Y. Ma, Y. Hao, Effects of samarium addition on as-cast microstructure, grain refinement and mechanical properties of Mg-6Zn-0.4Zr magnesium alloy, Journal of Rare Earths, 35 (2017) 5, 494-502, doi:10.1016/S1002-0721(17) 60939-6

${ }^{16}$ Z. Hu, Q. Hua, H. Yan, X. P. Jie, Y. S. Rao, Effect of trace Sm addition on microstructure and mechanical properties of AZ61 magnesium alloys, Rare Metal Materials and Engineering, 45 (2016) 9, 2275-2281, doi:10.1016/S1875-5372(17)30016-4

${ }^{17}$ M. Sun, X. Y. Hu, L. M. Peng, P. H. Fu, Y. H. Peng, Y. H. Peng, Effects of $\mathrm{Sm}$ on the grain refinement, microstructures and mechanical properties of AZ31 magnesium alloy, Materials Science and Engineering A, 620 (2015) 1, 89-96, doi:10.1016/j.msea.2014. 09.106

${ }^{18}$ Y. C. Zhao, S. H. Yan, Z. A. Li, S. M. Pang, D. H. Chen, W. Cheng, Influence of $\mathrm{Sm}$ on microstructure and mechanical properties of Mg-Zn-Y alloys, Chinese Journal of Rare Metals, 35 (2011) 5, 667-672, doi:10.3969/j.issn.0258-7076.2011.05.007

${ }^{19}$ Y. Kawamura, K. Hayashi, A. Inoue, T. Masumoto, Rapidly solidified powder metallurgy MgZn1Y2 alloys with excellent tensile yield strength above $600 \mathrm{MPa}$, Materials Transactions, 42 (2001) 7, 1172-1176, doi:10.2320/matertrans.42.1172

${ }^{20}$ E. Abe, Y. Kawamura, K. Hayashi, A. Inoue, Long-period ordered structure in a high-strength nanocrystalline Mg-1at\%Zn-2at\% Y alloy studied by atomic-resolution Z-contrast STEM, Acta Materialia, 50 (2002) 15, 3845-3857, doi:10.1016/S1359-6454(02)00191-X

${ }^{21}$ S. S. Park, G. T. Bae, D. H. Kang, B. S. You, N. J. Kim, Superplastic deformation behavior of twin-roll cast $\mathrm{Mg}-6 \mathrm{Zn}-1 \mathrm{Mn}-1 \mathrm{Al}$ alloy, Scripta Materialia, 61 (2009) 2, 223-226, doi:10.1016/j.scriptamat. 2009.03.057 